\title{
The Importance of Translanguaging in Improving Fluency In Speaking Ability of Non-English Major Sophomores
}

\author{
Tran Thi Thu Ha ${ }^{1}$ - Thach Thi Ngoc Phan ${ }^{1 *}$ - Tran Hoang Anh ${ }^{1}$ \\ ${ }^{1}$ Language Institute, Van Lang University, Vietnam \\ *Corresponding author. Email: thach.ptn@vlu.edu.vn
}

\begin{abstract}
This observational study aims to investigate the use of translanguaging to foster speaking fluency development among students at a university in the south of Vietnam. A total of individual 70 sophomores were tracked over eight weeks and studied in 4 modules conducted in a translanguaging instructional context. The findings suggest that the students had a positive experience with the lesson that included translanguaging resources and did promote students' speaking ability. Their use of L1 is reported to be a supportive approach in increasing their confidence and fluency in communication when learning English. Also, the results indicate that the students' language in the English lesson contributed to a positive change in behavior, engagement, and motivation. The implication of this study suggests that there is a need for more focus to be put on the use of a blending approach when teaching and learning the English language. In addition, teachers need to be formally trained in using translanguaging and supported in their use of translanguaging in alignment with current language policies and programs.
\end{abstract}

KEYWORDS: Speaking fluency, translanguaging, low level, motivation

\section{INTRODUCTION}

Fluency in English speaking is often defined as a high degree of proficiency in English- the fluency of an educated native speaker [22] or an automatic procedural skill [5] or the features which give the speech the qualities of being natural and normal, including native-like use of pausing, rhythm, intonation, stress, rate of speaking, and use of interjections and interruptions [19]. According to those definitions, the students can only achieve fluency when they devote time to practice, fulfill the assessment needs, and repeat the activity in the limited time constraint [3.16]
Fluency in speaking English is not only a communicative need but also a work-quest. Therefore, making a foundation and improving fluency in English speaking skills of the students, who mainly learn receptive skills, is a quest in any university program. Mckay and Brown [14] mention the two steps to develop English as an international language (EIL) fluency: teaching the students the strategies for handling linguistic and cultural differences in various contexts and then encouraging the performance of those languages (mentioned in step 1) in groups, pairs, task-based activities so that 
the students will learn the skills necessary to communicate effectively. This is achievable but needs many efforts since the students face many troubles ranging from their own characteristics, their linguistic levels, and their adaptation to the learning environment. To build the students' fluency ability, especially with low level students, translanguaging is considered as one of the effective strategies that can help.

\section{LITERATURE REVIEW}

The students' language performance is influenced by many elements. As Stokols [20] said, "on the basis of the social-ecological model, an individual's behavioral choices are affected through the dynamic interplay between individual characteristics and environmental features."

\subsection{Speaking Difficulties}

There are many elements that cause the student's speaking difficulties. The primary difficulty is the students' linguistic backgrounds. They often refuse to practice and speak English in class partly because of their linguistic backgrounds. According to Lukitasari [13], linguistic problems like pronunciation, grammar, and vocabulary hinder students from speaking English well in class. The most common difficulties that the students are afraid of include knowledge about new vocabulary, their pronunciation, grammatical structures, and how to put words appropriately to form sentences while speaking. Liu [12] also has the same opinion when explaining the fact that some students are reluctant to speak due to anxiety. It may be caused by low English proficiency, lack of practice, competition, and tasks difficulty. It is especially true with non-majored students, who are not familiar with using English at high schools and have no or little interest in English in comparison to their major.

Besides the trouble in the level of background knowledge, the students' own characteristics also influence their speaking, such as their own personality, and their level of anxiety. Thee psychological matters, Park and Lee [21] agree that those matters play an important role in affecting students' speaking performance. Depending on their own manners, the students have different styles of living, and thus, different styles of learning, especially in speaking. Some are always ready to speak out the target language. Some need time for careful preparations. Some often keep quiet due to their shyness or fear of losing face. About the student's anxiety, Horwitz and Young [9] described that anxiety is an obstacle when we are learning foreign languages and trying to speak up. However, learningenvironment-relatedd difficulties do not completely hinder students from speaking [23]. Those psychological difficulties just play roles as reluctant factors which may (or may not) affect students' speaking abilities to a certain degree.

\subsection{Motivation}

Students' motivation in learning English correlates significantly to the students' speaking competence [6]. There are two main kinds of students' motivation: Integrative and Instrumental. Integrative motivation refers to "an openness to identify at least in part with another language community " [15]. Integrative motivation is mainly developed by the students themselves with just a little influence from the environment. However, instrumental motivation is the one that can be more easily influenced by educators, as Gardner and Masgoret in Nawaz [17] define - the desire from learners to get a social and economic reward, like getting a good salary or getting into college. Therefore, what the teacher can mostly do is increase the students' instrumental motivation by encouraging the students' interaction and meaning negotiation during classes. It has been observed that students who interact and speak achieve better oral skills in most cases than those who always keep silent [15].

\subsection{Translanguaging}

Translanguaging is seen as an effective way to motivate students to speak and partly help them overcome the psychological problems they face with their low linguistic abilities. Originally, Cen Williams first used the term Translanguaging (in Welsh) to refer to pedagogical practices in which English and Welsh were used for different activities and purposes. Then, Baker [1] translated the term into English as "Translanguaging." In his definition, he refers to it as the ability to use the linguistic resources of bilingual people to make meaning and communicate.

There are two versions within the translanguaging theory: the weak version and the strong version. In the strong version, translanguaging prefers to the ability that the learners build a single linguistic repertoire by selecting appropriate features. The educators play an important role in constructing the language categories, regulating language use, 
maintaining the standard of languages [18]. It is different from code-switching, as "When the bilinguals select and deploy their linguistic features to communicate (translanguaging), it appears as if they are using two separate codes to communicate (code-switching). However, code-switching preserves named language categories intact when translaguaging dismantles named language categories. It means that they learn through social interactions, and from which they select and deploy features to make meaning in context"[24].

The benefits that translanguaging can bring to the students' speaking ability lie in its pedagogy's core components [8]. The first component is "stance"- a belief that students' diverse linguistic practices are valuable resources in developing their levels. The second is "design"- the design of lessons driven by the students. The last is "shift"- an ability to make flexible changes in lessons, based on the students' feedback. It is also because of translanguaging pedagogy's interrelated purposes of use [8]: providing opportunities to develop linguistic practices for academic contexts, making space for students' bilingualism, and supporting the students' bilingual identities and social-emotional development.

Generally, "a translanguaging pedagogy develops both of the named languages that are the object of bilingual instruction precisely because it considers them in a horizontal continuum as part of the learners' linguistic repertoire, rather than as separate compartments in a hierarchical relationship.” [8]

\section{THE STUDY}

\subsection{Design}

The study was designed as a time-series investigation, in which 70 sophomores studying English at university, who had already studied 90 in-class periods in modules one and two, were randomly sampled by the cluster sampling scheme.

\subsection{Context and Participants}

The participants are studying at Van Lang University, in their English module three. In the first and second modules, the students were supposed to study A2 plus to B1 minus level, with forty-five in-class periods. In module three, the students were supposed to study B1 minus level, also with forty-five in-class periods.
The participants' levels are mixed, with the low to medium level of English, around A2, and few students with B1 minus level.

\subsection{Data Collection Procedure}

The first questionnaire was delivered to seventy participants at the beginning of the course with the purpose of diagnosing the students' current levels and attitudes toward English speaking.

The in-class teaching and observation is carried out with the purpose of instructing the students to practice using translanguaging every time they speak (both in pairs, groups, and public speaking)

The second questionnaire is delivered at the course end with the aim of tracking the students' level of speaking English. There are 69 students participating in answering the second questionnaire.

\subsection{Measurements of endpoints}

The primary endpoint is increasing the student's speaking ability in English. The secondary endpoint is increasing the students' confidence in communicating with others, especially in public speaking.

\subsection{Data analysis}

Descriptive statistics were run to reveal patterns in the students' fluency in speaking ability at the beginning of the course and tracked their progress at the end of the course. Percentages were calculated. The data were tabulated, and teachers' and students' open comments on the use of translanguaging were analyzed to add evidence to the quantitative results.

\section{FINDINGS AND DISCUSSION}

\subsection{The first questionnaire}

In the first questionnaire, the student's current level of fluency and their confidence in speaking are studied.

Firstly, in figure 1, although the students' level is mixed in the study, the majority of them self-evaluate themselves in the medium level $(51.4 \%)$ and weak $(34.3 \%)$ 


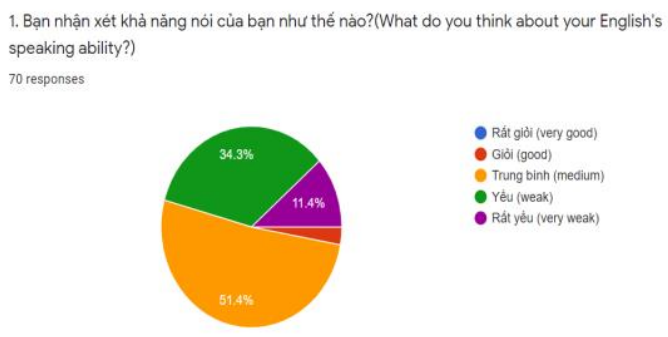

Figure 1: The English speaking ability

Secondly, in figure 2, the data collected in the second question is consistent with the first one as the majority of the students report that they are not confident in using English.

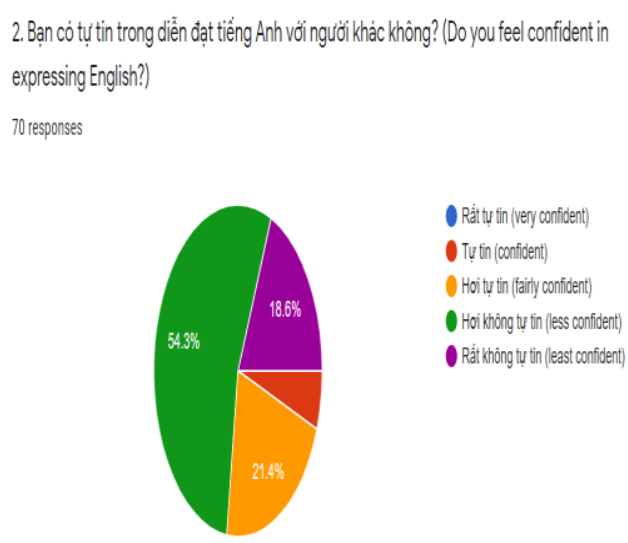

\section{Figure 2: the confidence of using English}

Next, in figure 3, although the way the students used when facing the problems of their incompetence in English fluency, nearly 90 percent of them subconsciously use translanguaging (with the use of mother tongue, and gesture, posture, objects descriptions...) to describe their ideas.

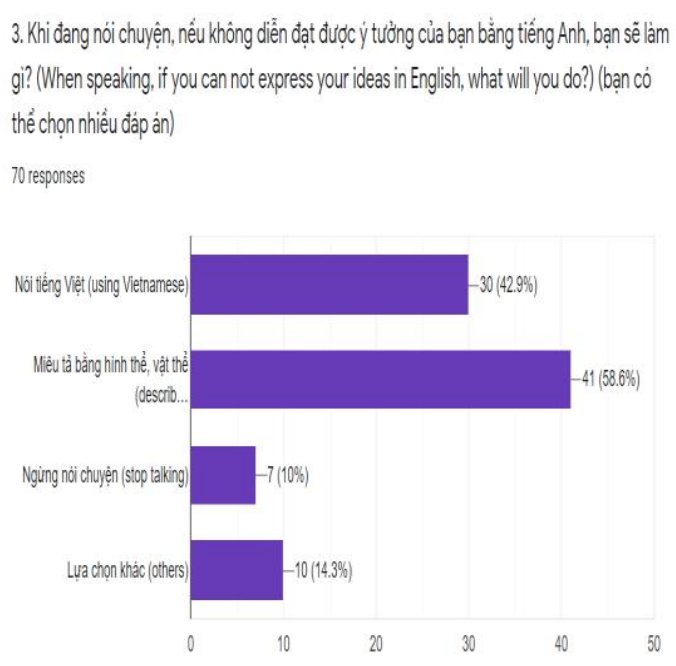

Figure 3: Ways to express English

To sum up, the data of the first questionnaire shows that the students are mainly at the low level and thus do not have much confidence in speaking out the language. However, they are unconsciously use translanguaging in their communication.

\subsection{The second questionnaire}

In the second questionnaire, the student's confidence in speaking, their level of fluency when applying translanguaging, their general speaking ability, and their future trend to further enhance their English speaking skills are studied.

To begin with, in figure 4 , the majority of the students agree that their confidence in expressing English is increasing. To make clear this point, around 82 percent of the participants report that they are more confident or fairly more confident with their English speaking. Moreover, another positive signal is that, in comparison with the start-of-course questionnaire, none of them report that they are at the lowest point of the confidence scale. In addition, the percentage of the "less confident" and "least confident," which is even lower than the percentage of "less fluent" and "least fluent" (as shown in Figure 5) show another benefit of translanguaging that is despite the student's lower level in fluency, their confidence in speaking out the target language- one of the decisive elements to be fluent in this languageis increasing. 


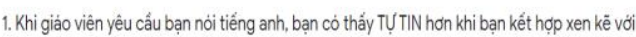
dưng tiếng việt, miêu tà bẳng hinh thể và vạt t thê?? (when speaking English, Do you feel more confident when combining English, your Vietnamese, and illustrations with objects and body languages?)

69 responses

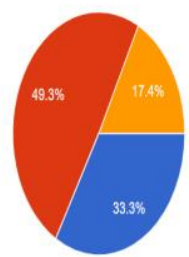

- Tu tu hon (more confident) - Hoi ty tin hon (farly more confident)

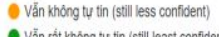
- Vẳn rát khóng tu tin (sill least confidern)

\section{Figure 4: the confidence after the course}

Secondly, in figure 5, the participants' fluency level is also better due to the use of translanguaging. Around 73 percent of the participants report that they have a gradual improvement in fluency (more fluent and fairly more fluent). The result partly shows that using translanguaging can help to increase the student's fluency, but it cannot be effective with all the students in achieving their linguistic targets (with 25 percent of them showing the vague signal or no upgrading in their fluency level)

2. Khi giáo viên yêu cẩu bạn noi tiểng anh, bạn có thấy bạn nói LUUU LOÁT hơn khi bạn kết hợp xen kẽ với dủng tiếng việt, miêu tả bằng hinh thể và vật thể? (when speaking English, Do you feel more fluent when combining English, your Vietnamese, and illustrations with objects and body languages?)

69 responses

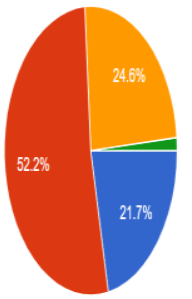

Luvloát hon (more fuent)

Hoil luu loat hon (farity more fluent) Vẫ khóng luu loät (still less fluent) - Vẫn rát không luu loảt (still leass fluent)

\section{Figure 5: the fluency after the course}

Thirdly, the result of the third question shown in figure 6 , which strongly links to the first and the second question in the second questionnaire, shows the improvement of the majority in their speaking skill. In this study, about 80 percent of the students reveal that their fluency is becoming better than their level at the course's beginning. Especially, 11.6 percent of them have approved that they are changing completely better (they choose the highest mode in the survey's scale).
4. So với đẩu khóa học, Bạn nhận xét khả năng noi của bạn như thế nào? (What do you think about your English's speaking ability in comparision with yours at the beginning of the course?)

69 responses

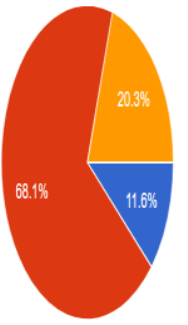

0 Thay ởi tot hon (becoming better)

0 Thay ởi khà toth hon (becoming farity better)

Khöng thay dồ (Keeping the same)

Tệ hon so voí ẩa khóa học (becooming worse)

Rát tệ so vơi đẩu khóa học (becoming extremely worse)

\section{Figure 6: The speaking ability after the course}

Lastly, in figure 7, the study also indicates when reaching a certain fluency level, the students have a trend of not using translanguaging often and improving their speaking fluency through linguistic resources instead. To illustrate this point, when being asked about how to improve their fluency performance, the majority of the students agree that when their fluency is basically formed, they need the "real" resource (autonomy, interaction, linguistic inputs) for stable and sustainable development in their linguistic ability, rather than relying heavily on a methodical aid, such as translanguaging. For example, only 26.1 percent of the participants state that they will continue using translanguaging to improve their fluency performance, while 76,8 percent of the students state that they will improve their vocabulary and grammar, and 44.9 percent of them will improve their speaking skills through interactions and self-studying.

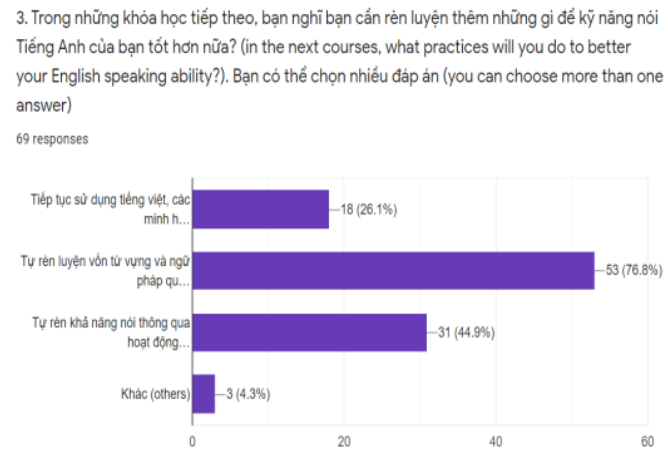

Figure 7: further improvement methods

To sum up, the data of the second questionnaire shows a certain positive result of translanguaging in the majority of the students, especially in their confidently speaking out the target language, and the students' trend of improving their speaking fluency 
through linguistic resources instead of using translanguaging when reaching a certain level of fluency in English speaking skill.

\section{DISCUSSIONS}

At the beginning of the course, nearly four-fifths of the students are not fluent, and thus, not confident in speaking English. After the course, there is about three-fourths of the participants find translanguaging helpful to their speaking level's improvement. The finding in this study is consistent with the ones in other studies about the ability of multilingual speakers using translanguaging to shuttle between languages [4], or the belief that bilingual students can participate in more situations when allowed to trans language [7].

Even with those who report that translanguaging does little or even no help to their speaking level's improvement, they still agree that they have a slight improvement in their confidence in expressing themselves in English, which are believed to lead to their future improvement in their fluency.

Another finding is that around half to two-thirds of the students realize that translanguaging is only a temporary way to help them overcome the fear of speaking English and be able to speak better. Thus, they need to have learning autonomy, interaction, and linguistic input improvement to boost their fluency performance. It is the same as a result from Lewis, Jones, and Baker [10] that translanguaging provides scaffolding and support that can be removed when children are more advanced in their language competence.

\section{CONCLUSION AND IMPLICATIONS}

Translanguaging is used as an effective way to help the majority of low-leveled students overcome the fear of speaking English because it boosts the participants' confidence. And thus, it can also help to improve the students' fluency in speaking.

With the participants reporting improvement, the educators should depend on the students' levels to have adequate use of translanguaging in the class. For example, at the very beginning of the course or at the students' low-level stages, translanguaging should be used more often to encourage the students' confidence. Then, when the confidence is gradually built up, the "real" input for the fluent performance, such as vocabulary, grammar, should be gradually, continually, and logically added. Moreover, to maximize the students' fluency, it should be combined with the students' self-studying and group/pair studying.

With those who report very little or even no positive change in their fluency, there is a need for the teachers to get those students tested, arrange them into extra classes based on that results, provide them extra lessons (with more input or repetitive practice). It is also necessary that they be more autonomous in their self-studying and group/ pairs interaction.

It is also suggested that another further time-series investigation with the purposive sampling scheme should be done to find out the reasons, and thus suggest some solutions, for the retrogression in English fluency of the students when studying with the aids of translanguaging.

\section{ACKNOWLEDGMENTS}

The authors of this article acknowledged the supports of Van Lang University at 69/68 Dang Thuy Tram St. Ward 13, Binh Thanh Dist., Ho Chi Minh City, Vietnam.

\section{REFERENCES}

[1] Baker, C., Foundations of bilingual education and bilingualism., Bristol, UK: Multilingual Matters, 2001.

[2] Bashir, M., Azeem, M., \& Dogar, A. H., Factor Affecting Students' English Speaking Skills. British Journal of Arts and Social Sciences, 2(1), 2011, pp. 34-50.

[3] Bygate, M., \& Samuda, V.. Integrative planning through the case of task-repetition. In R. Ellis (Ed.), Planning and task performance in a second language, Amsterdam: John Benjamins, 2005, pp. 37-74.

[4] Canagarajah, S.. "Codemeshing in Academic Writing: Identifying Teachable Strategies of Translanguaging." Modern Language Journal. 95: 401-417. DOI: 10.1111/j.1540-4781.2011.01207.x

[5] Carlson, R. A., Sullivan, M., \& Schneider, W., Practice and working memory effects in building procedural skill. Journal of Experimental Psychology: Learning, memory, and Cognition, 15,1989 , pp. 517-526.

[6] Damaris E. Silalahi. Correlation between Students' Learning Motivation and speaking Competence at SFL FKIP University HKBP Nomensen. International Journal of English Literature and Social Sciences (IJELS), Vol. 3, 
Issue-6,2018, pp. 992- 995. DOI: https://dx.doi.org/10.22161/ijels.3.6.11

[7] García, O., Bilingual Education in the 21st Century: A Global Perspective, Chichester: Wiley-Blackwell, 2009.

[8] Garcia, O., Johnson, S., \& Seltzer, K., The translanguaging classroom. Leveraging student bilingualism for learning, Philadephia: Caslon, 2017.

[9] Horwitz, E. K., \& Young, D. J. (Eds.)., Language anxiety: From theory and research to classroom implications, Englewood, NJ: Prentice Hall, 1991.

[10] Lewis, G., B. Jones, and C. Baker, "Translanguaging: Developing its Conceptualisation and Contextualization." Educational Research and Evaluation: An International Journal on Theory and Practice 18, 2012b, pp. 655-670. DOI: $10.1080 / 13803611.2012 .718490$

[11] Littlewood, W., Communicative Language Teaching, Cambridge: Cambridge University Press, 2007.

[12] Liu, Meihua. "Anxiety in Oral English Classrooms: A Case Study in China." Indonesian Journal of English Language Teaching 3.1, 2007a, pp. 119-137. Google Scholar. Web. 11 November 2011.

[13] Lukitasari, N., Students' Strategies in Overcoming Speaking Problems in Speaking Class, Malaysia: University of Muhammadiyah Malang, 2003.

[14] Mckay, S.L. \& Brown, J.D., Teaching and assessing Oracy. In teaching and assessing EIL in local contexts around the World, New York: Routledge, 2016, pp. 86-112.

[15] Namaziandost, E., Hashemifardnia, A., \& Shafiee, S., The impact of opinion-gap, reasoning-gap, and information-gap tasks on EFL learners' speaking fluency, Cogent Social Sciences, $\quad 5, \quad 1630150, \quad 2019$. DOI:10.1080/23311886.2019.1630150

[16] Nation, I. S. P., Improving speaking fluency, System, 17(3), 1989, pp. 377-384.

[17] Nawaz. A, Bibi. N, Sheikh. A, Bilal, H.A, Rehman. A., The Role of Motivation in Learning English Language for Pakistani Learners. International Journal of Humanities and Social Science, Vol. 4, 2014, pp. 254- 258.
[18] Other guy, R., Garcia,O., \& Reid, W., Clarifying translanguaging and deconstructing named languages: a perspective from linguistics. Applied Linguistics Review, 6(3), 2015, pp. 281-307.

[19] Richard, J.C., \& Schmidt, R., Longman dictionary of language teaching and applied linguistics (3rd edition), London, UK: Longman, Pearson Education, 2002.

[20] Stokols, D., Establishing and maintaining healthy environments: toward a social ecology of health promotion, American Psychologist, 47(1), 1992, pp. 6-22.

[21] Park, H., \& Lee, A.R., L2 Learners' Anxiety, Self-confidence and Oral Performance, Proceedings of the 10th Conference of Pan-Pacific Association of Applied Linguistics (pp. 107-208), Edinburgh University, August 2005, Retrieved January, 25th, 2011 from http://www.paaljapan.org/resources/proceedings /PAAL10/pdfs /hyesook.pdf.

[22] Timmis, I., Native-speaker norms and international English: A classroom view. Oxford, UK: Oxford University Press, 2002.

[23] Thao, Tran \& Duong, Tran. 'Non-English major's English speaking difficulties: a case study, The 8th Open TESOL International conference 2020, 23rd May, Ho Chi Minh City Open University, pp. 241-262.

[24] Vogel, S. \& Garcia, O., Translanguaging. In G.Noblit \& L.Moll (Eds.). Oxford Research Encyclopedia of Education, Oxford: Oxford University Press, 2017, pp. -21.

[25] Woodrow, L., Anxiety and Speaking English as a Second Language. RELC Journal, 37(3), 2006, pp. 308-328. 